\title{
Observations of iodine monoxide over three summers at the Indian Antarctic bases of Bharati and Maitri
}

\author{
Anoop S. Mahajan ${ }^{1}$, Mriganka S. Biswas ${ }^{1,2}$, Steffen Beirle ${ }^{3}$, Thomas Wagner $^{3}$, Anja Schönhardt ${ }^{4}$, Nuria Benavent ${ }^{5}$, \\ and Alfonso Saiz-Lopez ${ }^{5}$ \\ ${ }^{1}$ Centre for Climate Change Research, Indian Institute of Tropical Meteorology, \\ Ministry of Earth Sciences, Pune, 411008, India \\ ${ }^{2}$ Atmospheric and Space Sciences, Savitribai Phule Pune University, Pune, 411008, India \\ ${ }^{3}$ Satellitenfernerkundung, Max-Planck-Institut für Chemie (MPI-C), 55128 Mainz, Germany \\ ${ }^{4}$ Department of Physics and Electrical Engineering, Institute of Environmental Physics, \\ University of Bremen, 330440 Bremen, Germany \\ ${ }^{5}$ Department of Atmospheric Chemistry and Climate, Institute of Physical Chemistry Rocasolano, \\ CSIC, 28006 Madrid, Spain
}

Correspondence: Anoop S. Mahajan (anoop@tropmet.res.in)

Received: 25 September 2020 - Discussion started: 20 November 2020

Revised: 28 April 2021 - Accepted: 30 April 2021 - Published: 9 August 2021

\begin{abstract}
Iodine plays a vital role in oxidation chemistry over Antarctica, with past observations showing highly elevated levels of iodine oxide (IO) leading to severe depletion of boundary layer ozone in West Antarctica. Here, we present MAX-DOAS-based (multi-axis differential absorption spectroscopy) observations of IO over three summers (20152017) at the Indian Antarctic bases of Bharati and Maitri. IO was observed during all the campaigns with mixing ratios below 2 pptv (parts per trillion by volume) for the three summers, which are lower than the peak levels observed in West Antarctica. This suggests that sources in West Antarctica are different or stronger than sources of iodine compounds in East Antarctica, the nature of which is still uncertain. Vertical profiles estimated using a profile retrieval algorithm showed decreasing gradients with a peak in the lower boundary layer. The ground-based instrument retrieved vertical column densities (VCDs) were approximately a factor of 3 to 5 higher than the VCDs reported using satellite-based instruments, which is most likely related to the sensitivities of the measurement techniques. Air mass back-trajectory analysis failed to highlight a source region, with most of the air masses coming from coastal or continental regions. This study highlights the variation in iodine chemistry in different regions in Antarctica and the importance of a long-term
\end{abstract}

dataset to validate models estimating the impacts of iodine chemistry.

\section{Introduction}

Reactive halogen species (RHS) have been shown to play a critical role in causing ozone depletion events in the polar boundary layer (BL) (Barrie et al., 1988; Bottenheim et al., 1986; Kreher et al., 1997; Oltmans and Komhyr, 1986) and could contribute to new particle formation in this remote environment (Allan et al., 2015; Atkinson et al., 2012; O'Dowd et al., 2004). Observations of RHS have been made in the Antarctic BL for almost two decades. Early observations focused on bromine oxide ( $\mathrm{BrO})$, the presence of which was observed in the Antarctic using ground-based instruments (Kreher et al., 1997) and via satellites (Hollwedel et al., 2004). The presence of iodine oxide (IO) in the Antarctic atmosphere was also confirmed through integrated column measurements from the ground (Frieß et al., 2001). Later, year-long ground-based observations of RHS made at Halley Bay showed the critical role that bromine and iodine compounds play in regulating the oxidizing capacity, causing ozone depletion and new particle formation in the Antarctic BL (Saiz-Lopez et al., 2007a). These ground-based ob- 
servations show that both $\mathrm{IO}$ and $\mathrm{BrO}$ are present at elevated concentrations (from 1 to as high as $20 \mathrm{pptv}$ ) in certain parts of the Antarctic BL and show a significant seasonal variation peaking in the spring, with elevated concentrations observed through the summer (Saiz-Lopez et al., 2008). Satellite-based observations of both $\mathrm{IO}$ and $\mathrm{BrO}$ reported a similar annual cycle, although with large geographical differences (Hollwedel et al., 2004; Richter et al., 2002; SaizLopez et al., 2007b; Schönhardt et al., 2008, 2012; Theys et al., 2011; Wagner et al., 2001). These satellite observations have been validated by ground-based observations, although most of them have hitherto focused on the area around the Weddell Sea (Atkinson et al., 2012; Buys et al., 2013; Frieß et al., 2001, 2010; Saiz-Lopez et al., 2007a, 2008). Previous studies show that similar levels of $\mathrm{BrO}$ have been observed between the Arctic and Antarctic, while much lower levels of atmospheric iodine have been reported in the Arctic compared to the Antarctic (Hönninger et al., 2004; Raso et al., 2017; Schönhardt et al., 2008; Tuckermann et al., 1997). The satellite observations also show a difference in the geographical distribution of IO over Antarctica, with the Weddell sea being an iodine hotspot, the reasons for which are still not completely clear (Saiz-Lopez and Blaszczak-boxe, 2016). Ground-based observations have also been made at McMurdo Sound, near the Ross Sea, where lower concentrations of IO were observed (Hay, 2010). Additional observations over the 2011-2012 summer were made at Dumont d'Urville Station using a cavity-enhanced absorptionspectroscopy-based instrument and showed a maximum of 0.15 pptv of IO (Grilli et al., 2013). However, observations of IO have not been reported in the Indian Ocean sector of the Antarctic peninsula to date (Saiz-Lopez et al., 2012; SaizLopez and von Glasow, 2012).

Ground-based observations at Halley Bay and in the Weddell Sea suggest that the main source of iodine compounds is the sea ice region based on observations of iodocarbons and back trajectory analysis (Atkinson et al., 2012; Saiz-Lopez et al., 2007a). Other studies have also measured iodocarbons in Antarctica, although their levels are too low to explain the high levels of IO observed in the Weddell Sea region (Carpenter et al., 2007; Fogelqvist and Tanhua, 1995; Reifenhäuser and Heumann, 1992). The exact process is still not known, although a mechanism for biologically induced iodine emissions from sea ice has been suggested based on the idea that micro-algae (Garrison and Buck, 1989) are the primary source of iodine emissions in this environment (SaizLopez et al., 2015a), with halogen compounds then moving up brine channels in the sea ice to finally get released into the atmosphere. There are further questions regarding the propagation of reactive iodine chemistry across the continent because satellite observations show the presence of IO deep within the Antarctic continent, even as far as the South Pole (Saiz-Lopez et al., 2007b; Schönhardt et al., 2008). However, although enhanced, the observed IO column densities are close to the detection limit of the satellite instru- ment $\left(\sim 7 \times 10^{12}\right.$ molec. $\mathrm{cm}^{-2}$ for a single measurement) and are therefore subject to uncertainties. The study by Frieß et al. (2010) suggested a strong source within the snowpack, which hints at active recycling and re-emission of IO aiding the long transport inland. However, questions remain about why such a source would function only in parts of the continent and why the primary source is different from the Arctic, where much lower peak concentrations are sporadically observed (Mahajan et al., 2010; Saiz-Lopez and Blaszczakboxe, 2016). To further understand the sources of iodine in the polar environment, understanding the geographical distribution is critical. Satellite observations play a useful role for this, although validation of the satellite observations using ground-based instruments is necessary to ascertain their accuracy when observing IO in the Antarctic troposphere.

Questions also remain about the vertical profiles of iodine compounds within and above the Antarctic boundary layer. Modeling-based studies using the one-dimensional Tropospheric Halogen Chemistry MOdel (THAMO) have suggested a strong gradient in IO from the surface to the edge of the boundary layer (Saiz-Lopez et al., 2008). Only once in the past have vertical profiles of IO been measured in Antarctica using the multi-axis differential optical absorption spectroscopy (MAX-DOAS) instrument. These measurements were made at McMurdo Sound in East Antarctica (Hay, 2010). Observations over 2 "golden days" in 2006 and 2007 show surface concentrations of about 1 pptv, decreasing to $\sim 0.2 \mathrm{pptv}$ at about $200 \mathrm{~m}$, before reaching a second maximum of $0.6 \mathrm{pptv}$ at $\sim 700 \mathrm{~m}$. The detection limit was estimated to be about $\sim 0.5$ pptv. However, models did not reproduce this measured IO vertical profile shape, and there are also large uncertainties associated with the a priori profile (Hay, 2010). In most models, the assumption is that the source of iodine compounds is from the snowpack, with photochemistry in the atmosphere resulting in a steady decrease with altitude. However, considerable challenges remain in reproducing the surface variation and vertical gradients in addition to the geographical distribution (Fernandez et al., 2019). More recent modeling studies combined with aircraft observations suggest that the gradient is not very sharp at all the latitudes, with a significant free tropospheric and stratospheric contribution to the total column of IO (Koenig et al., 2020; Saiz-Lopez et al., 2015b), although such observations have still not been done in the Antarctic. One of the main reasons for the uncertainties in models is the lack of consistent measurements of vertical gradients across the world, especially in the polar regions, to validate these model simulations.

Considering the uncertainties in the satellite observations and questions regarding the sources and vertical and geographical distribution of IO, further observations are necessary. Here we present observations made at two new locations in Antarctica over three summers and compare them with the satellite-based retrievals and past observations. 


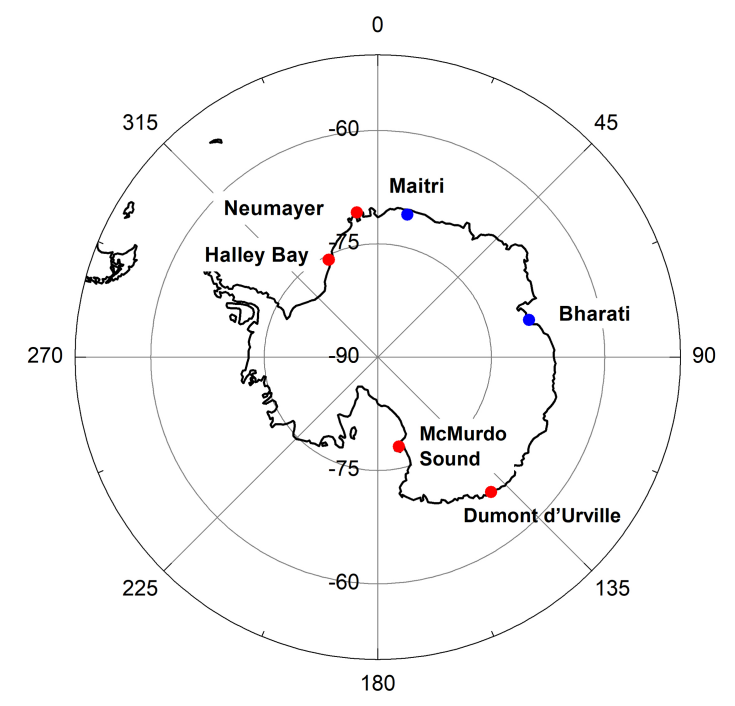

Figure 1. Map showing the location of the two Indian Antarctic stations, Maitri and Bharati, where observations of IO were performed during this study (blue dots). Previous locations that have reported observations of IO (Frieß et al., 2001; Grilli et al., 2013; Hay, 2010; Saiz-Lopez et al., 2007a) are also marked on the map (red dots).

\section{Methodology}

Figure 1 shows the location of the two Indian Antarctic stations, Maitri $\left(70.77^{\circ} \mathrm{S}, 11.73^{\circ} \mathrm{E}\right)$ and Bharati $\left(69.41^{\circ} \mathrm{S}\right.$, $\left.76.19^{\circ} \mathrm{E}\right)$. The other stations where observations of IO have been reported in the past are also marked on the map. Observations of $\mathrm{IO}$ and the oxygen dimer $\left(\mathrm{O}_{4}\right)$ were made using the multi-axis differential optical absorption spectroscopy (MAX-DOAS) technique over three summers: FebruaryMarch 2015 as part of the 34th Indian Scientific Expedition to Antarctica (ISEA-34), November 2015-February 2016 as a part of ISEA-35, and January-February 2017 as a part of ISEA-36.

Observations at Maitri station were made over a short span of $9 \mathrm{~d}(9-17$ March 2015) and only during ISEA-34. The research station is in the ice-free rocky area on the Schirmacher Oasis. The MAX-DOAS instrument was installed in a summertime residential container $\sim 150 \mathrm{~m}$ north of the station and about $120 \mathrm{~m}$ above sea level during ISEA-34. The scanner unit was mounted on top of the container with a clear line of sight to the horizon. The scanner pointed $\sim 60.0^{\circ}$ with respect to magnetic north. The spectrometer unit was kept inside the container, which was temperature controlled. The open ocean is $125 \mathrm{~km}$ north of Maitri.

Observations at Bharati station were made for $10 \mathrm{~d}$ (918 February 2015) during ISEA-34, for $63 \mathrm{~d}$ (30 November 2015-1 February 2016) during ISEA-35, and for 35d (5 January-11 February 2017) during ISEA-36. The station is located between the Thala Fjord and Quilty Bay, east of the Stornes Peninsula. The MAX-DOAS instrument was installed in a hut on top of a ridge around $200 \mathrm{~m}$ southwest of
Bharati station and was approximately $56 \mathrm{~m}$ above sea level. The scanner unit was mounted on the wall of the hut and had a clear line of sight to the horizon, pointing $-23.2^{\circ}$ with respect to north and overlooking the open ocean. The coastline is within $500 \mathrm{~m}$ of the hut, but it becomes ice free from mid-January to late March. Depending on the sea ice conditions, the open ocean is within $8-10 \mathrm{~km}$ north from the end of November.

The MAX-DOAS instrument (EnviMeS) makes use of scattered sunlight along different elevation angles and by the combination of several lines of sight including the zenith. The concentration of an absorber in the boundary layer can be obtained either in a first approximation by a simple geometric approach or by simulating the light path with a radiative transfer model also taking into account multiple scattering effects and the correct treatment of the aerosol loading in the atmosphere (Hönninger et al., 2004; Platt and Stutz, 2008; Wagner et al., 2004). The instrument consists of an indoor unit housing a spectrometer with a spectral resolution of $0.7 \mathrm{~nm}$ (UV: $301.20-463.69)$ which is connected to an outdoor unit containing a scanning telescope. Discrete elevation angles $\left(1,2,3,5,7,10,20,40\right.$, and $\left.90^{\circ}\right)$ were recorded for a total exposure time of $1 \mathrm{~min}$ each during all four campaigns. The spectra were recalibrated before analysis using mercury emission lines recorded at the end of each day. For DOAS retrieval, the QDOAS 3.2 software was used (Fayt and Van Roozendael, 2013). For estimation of the $\mathrm{O}_{4}$ differential slant column densities (DSCDs), the cross-sections of $\mathrm{O}_{4}$ (Thalman and Volkamer, 2013) at $293 \mathrm{~K} ; \mathrm{NO}_{2}$ (Vandaele et al., $1998)$ at 220 and $298 \mathrm{~K}(220 \mathrm{~K}$ orthogonalized to $294 \mathrm{~K}) ; \mathrm{O}_{3}$ (Bogumil et al., 2003) at 223 and $243 \mathrm{~K}$ (orthogonalized to $\mathrm{O}_{3}$ at $243 \mathrm{~K}$ ); $\mathrm{HCHO}$ (Meller and Moortgat, 2000) at $298 \mathrm{~K}$; and HONO (Stutz et al., 2000) at $296 \mathrm{~K}$ were used in the $351-$ $390 \mathrm{~nm}$ window. The cross-sections used for IO retrieval in the 417-440 nm spectral window were IO (Gómez Martín et al., 2005), $\mathrm{NO}_{2}$ at both 220 and $298 \mathrm{~K}$ (Vandaele et al., 1998), $\mathrm{H}_{2} \mathrm{O}$ (Rothman et al., 2013), $\mathrm{O}_{4}$ (Thalman and Volkamer, 2013), and $\mathrm{O}_{3}$ (Bogumil et al., 2003). In addition to these cross-sections a ring spectrum (Chance and Spurr, 1997), a second ring spectrum following Wagner et al. (2009), and the third-order polynomial were used for both windows. The zenith spectrum from each scan was used as a reference to remove the contribution from possible free tropospheric or stratospheric absorption. An example of a DOAS fit for $\mathrm{O}_{4}$ and IO are given in Fig. S1 in the Supplement. Surface mixing ratios and the total vertical column densities (VCDs) were retrieved from the MAX-DOAS DSCDs of IO and $\mathrm{O}_{4}$ by employing the Mainz profile algorithm (MAPA) (Beirle et al., 2018). Only observations with solar zenith angles (SZAs) less than $75^{\circ}$ were used for the profile retrievals due to the large path lengths through the stratosphere for large SZAs. This algorithm uses a two-step approach to determine the trace gas vertical profiles. In the first step, the aerosol profiles are retrieved using the measured $\mathrm{O}_{4}$ DSCDs. A Monte Carlo approach is utilized to identify the best ensemble of 

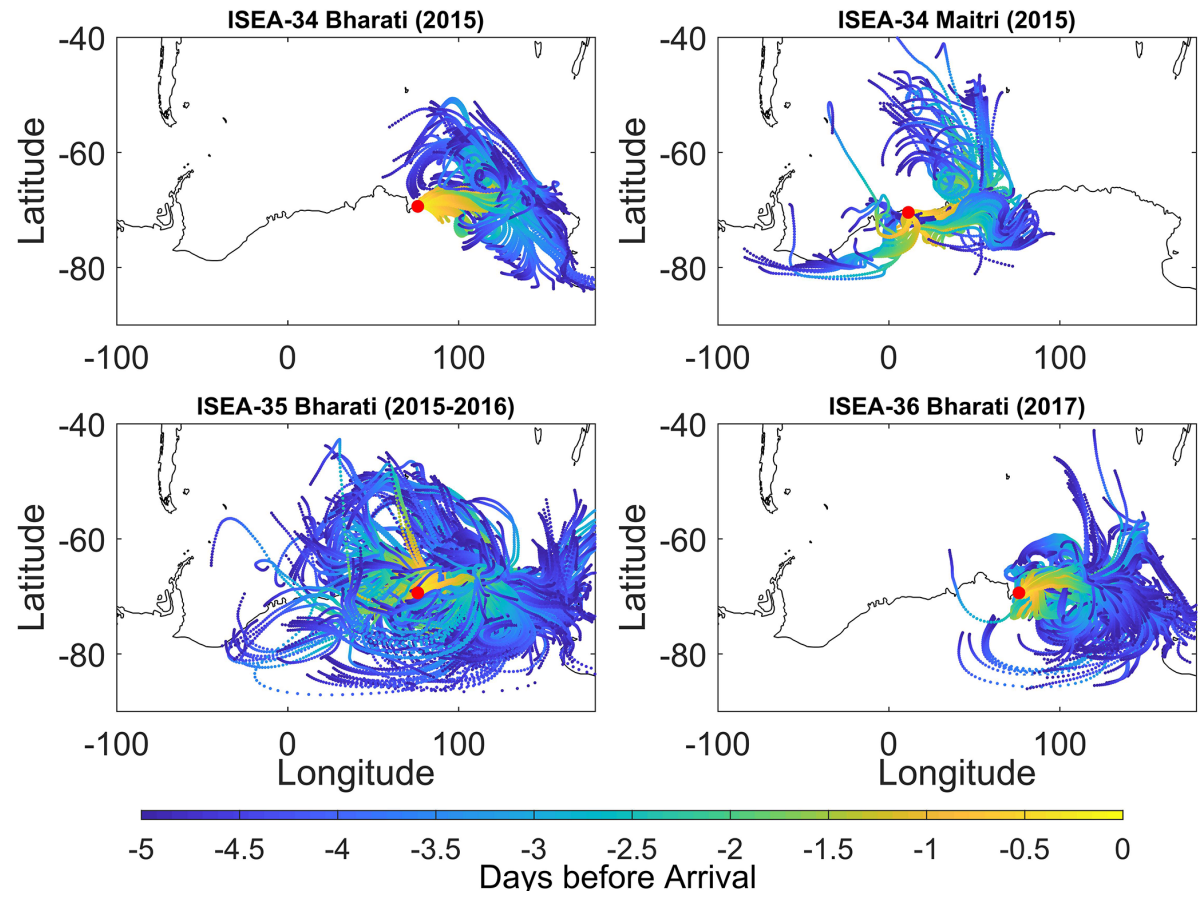

Figure 2. The $5 \mathrm{~d}$ back-trajectories arriving at the two stations on the days that the measurements of IO were conducted as a part of the 34 th, 35th, and 36th ISEA expeditions are shown. The back-trajectories were calculated using the HYbrid Single-Particle Lagrangian Integrated Trajectory (HYSPLIT) model, arriving every hour (Draxler and Rolph, 2003).

the forward model parameters - column parameter (c) (VCD for trace gases and aerosol optical depth for aerosol), height parameter $(h)$, and shape parameter $(s)$ - which fit the measured $\mathrm{O}_{4}$ DSCDs for the sequence of elevation angles. In the second step, the aerosol profiles retrieved from the $\mathrm{O}_{4}$ inversion are used as an input to retrieve similar model parameters $(c, h$, and $s)$ for IO. The state of the atmosphere was calculated using the pressure and temperature profiles observed by the in situ radiosondes, which were launched once a week at both stations. An Angstrom exponent of 1 was used for the difference in the retrieval wavelengths as per observations made at Bharati in the past (Prakash Chaubey et al., 2011). Within MAPA, the differential air mass factors (AMFs) are calculated offline with the radiative transfer model McArtim (Deutschmann et al., 2011) for fixed nodes for each parameter and stored as a lookup table (LUT) for quick analysis. To assess the quality of the retrievals, MAPA provides "valid", "warning", or "error" flags for each measurement sequence, which are calculated based on pre-defined thresholds for various fit parameters. For further details about MAPA, please refer to the description paper by Beirle et al. (2018). Additionally, MAPA provides the option to use a scaling factor for significant mismatch between the modeled and measured $\mathrm{O}_{4}$ DSCDs, which has been shown to be close to 0.8 in the past (Wagner et al., 2019). For this study, the scaling factor ranged between 0.75 and 0.9 . Therefore, a scaling factor of 0.8 was applied for all the campaigns.
We also make use of the IO vertical column densities retrieved using the SCanning Imaging Absorption spectroMeter for Atmospheric CartograpHY (SCIAMACHY), a UV-vis-NIR (ultraviolet-visible-near-infrared) spectrometer on board the ENVISAT satellite (Burrows et al., 1995). Observations from SCIAMACHY stopped due to instrumental problems in April 2012. Here we make use of the mean from 2004 to 2011 to look at the geographical distribution and compare it with the ground-based observations made during the study period. Further details about the IO retrieval algorithm and the SCIAMACHY instrumental setup can be found elsewhere (Schönhardt et al., 2008, 2012).

\section{Results and discussion}

\subsection{Meteorological parameters}

Figure 2 shows the $5 \mathrm{~d}$ back-trajectories arriving every hour at the two stations at a height of $10 \mathrm{~m}$ on the days that the DOAS measurements were conducted as a part of the three ISEA expeditions. The back-trajectories were calculated with the HYbrid Single-Particle Lagrangian Integrated Trajectory (HYSPLIT) model using the EDAS-40 km database (Draxler and Rolph, 2003). The trajectories show that the air masses sampled throughout the three expeditions were from either a remote oceanic region, coastal Antarctica, or the continental shelf. In general, most of the trajectories show that 

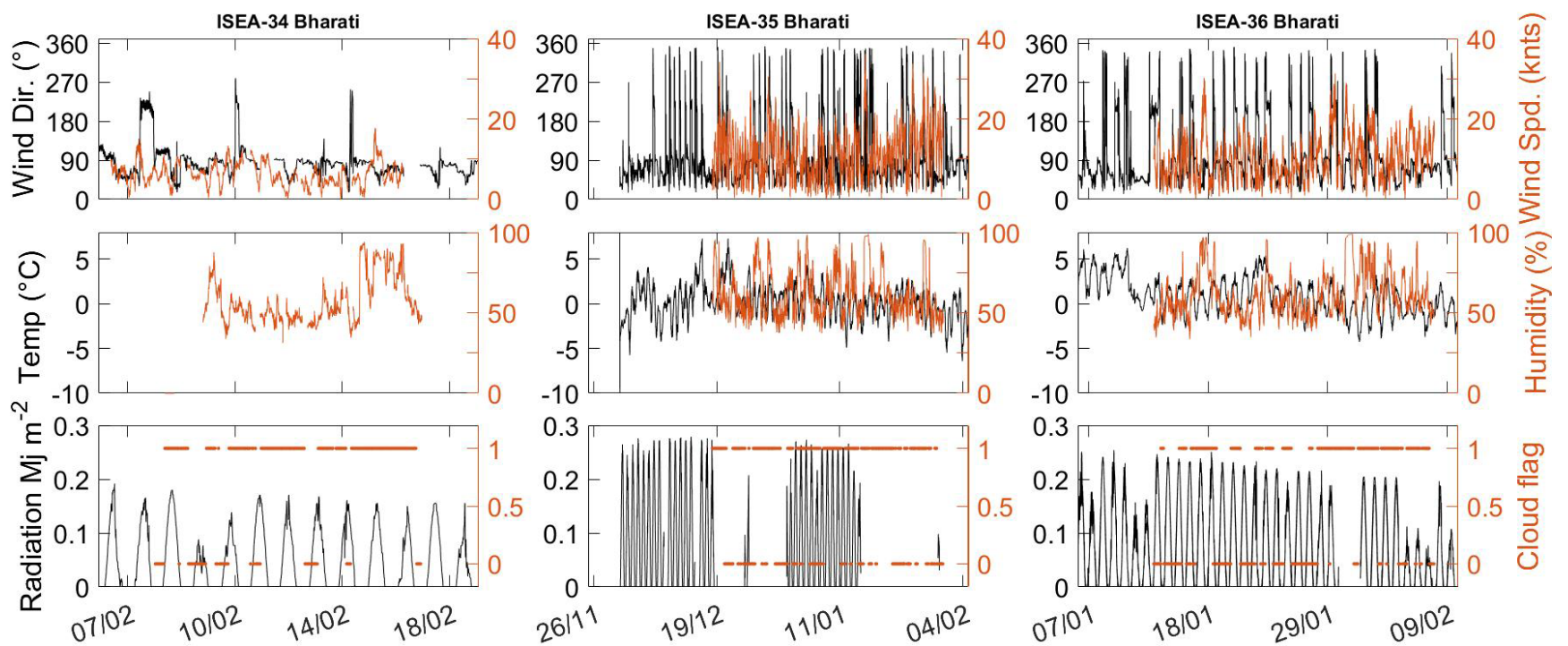

Figure 3. Observations of different meteorological parameters that were measured during the various summer campaigns are shown here. The top panels show the wind direction and speed, the middle panels show the temperature and humidity, and the bottom panels show the radiation and cloudiness ( 1 is defined as $30 \%$ cloudy skies and above). Observations of these parameters were not made during the 34 th ISEA at Maitri, and the gaps indicate instrumental or observational issues. The data had a time resolution of $5 \mathrm{~min}$.

the air masses had traveled hundreds of kilometers over the last 5 d. For the local meteorological conditions, Fig. 3 (top panels) shows the wind direction at Bharati station. Most of the time, the wind was from the ocean, with the winds coming from the northwest sector and a few instances of northern and northeastern winds (although during ISEA-34 the winds were mostly from east to northeast). This was during all three expeditions at Bharati station. The wind speed was mostly below $20 \mathrm{kn}\left(\sim 10 \mathrm{~m} \mathrm{~s}^{-1}\right)$ for all the campaigns, although periods of high winds were observed during ISEA-35 and ISEA-36, which were of a longer duration than ISEA-34. The temperature at the station hovered between -5 and $+5{ }^{\circ} \mathrm{C}$ throughout the summer period, with higher values closer to noon (Fig. 3, middle panels). The humidity fluctuated from $40 \%$ to above $90 \%$. The radiation followed a clear diurnal pattern, with the highest values seen around local noon and minima at local midnight. Considering that this region experiences continuous light for $24 \mathrm{~h}$, the radiation also showed a non-zero minima between November and January (Fig. 3, bottom panels). However, in February, a clear nighttime is seen in the radiation data. Finally, a measure of the cloudiness was also tracked using visual full sky cloud cover observations. Any cloud cover of more than $30 \%$ was considered to be cloudy (cloud flag value of 1), which helps in filtering the MAX-DOAS observations. In addition to the visual inspection of the sky, which was performed once an hour, a second cloud index was calculated based on the ratios of the radiances at 320 and $440 \mathrm{~nm}$ from the $3^{\circ}$ and zenith spectra (Mahajan et al., 2012; Wagner et al., 2014). Both manual and radiance-based indices showed a close match, indicating that cloudy conditions were well discerned by the cloud in- dex calculation. Meteorological data were unfortunately not available at Maitri station.

\subsection{Differential slant column densities (DSCDs)}

Figure 4 shows the observed $\mathrm{O}_{4}$ DSCDs at different elevation angles for all the campaigns. $\mathrm{O}_{4}$ DSCDs were found to be higher at lower elevation angles, as expected, which is because the $\mathrm{O}_{4}$ concentration is proportional to the square of the oxygen pressure and thus increases towards the surface. This also suggests that the aerosol loading was low in the atmosphere. Photons travel longer paths at lower elevation angles and interact more with tropospheric absorbing species before reaching the instrument, resulting in a decreasing profile with increasing elevation angles. The average residual root mean square (RMS) and $2 \sigma$ detection limit for the $\mathrm{O}_{4}$ DSCDs were $4.46 \times 10^{-4}$ (range: $1.56-10.01 \times$ $10^{-4}$ molec. $^{2} \mathrm{~cm}^{-5}$ ) and $2.11 \times 10^{42}$ molec. $^{2} \mathrm{~cm}^{-5}$ (range: $0.72-4.66 \times 10^{42}$ molec. $^{2} \mathrm{~cm}^{-5}$ ), respectively (Fig. 4). The $\mathrm{O}_{4}$ DSCDs were then used to estimate the aerosol profiles and hence the IO mixing ratios, as described earlier in Sect. 2.

Figure 5 shows the observed IO DSCDs at different elevation angles for all the campaigns. The IO DSCDs were found to be higher at lower elevation angles, which indicates a decreasing gradient in the IO vertical profile. The residual RMS was in the $1.15-9.73 \times 10^{-4}$ molec. $\mathrm{cm}^{-2}$ range (mean: $3.46 \times 10^{-4}$ molec. $\mathrm{cm}^{-2}$ ), resulting in $2 \sigma$ IO DSCD detection limits of $6.57 \times 10^{12}$ to $5.71 \times 10^{13}$ molec. $\mathrm{cm}^{-2}$ (mean $1.88 \times 10^{13}$ molec. $\mathrm{cm}^{-2}$ ) (Fig. 5). For several days, only the lowermost elevation angles were found to be above the $2 \sigma$ detection limit of the instrument. Higher IO DSCDs were 

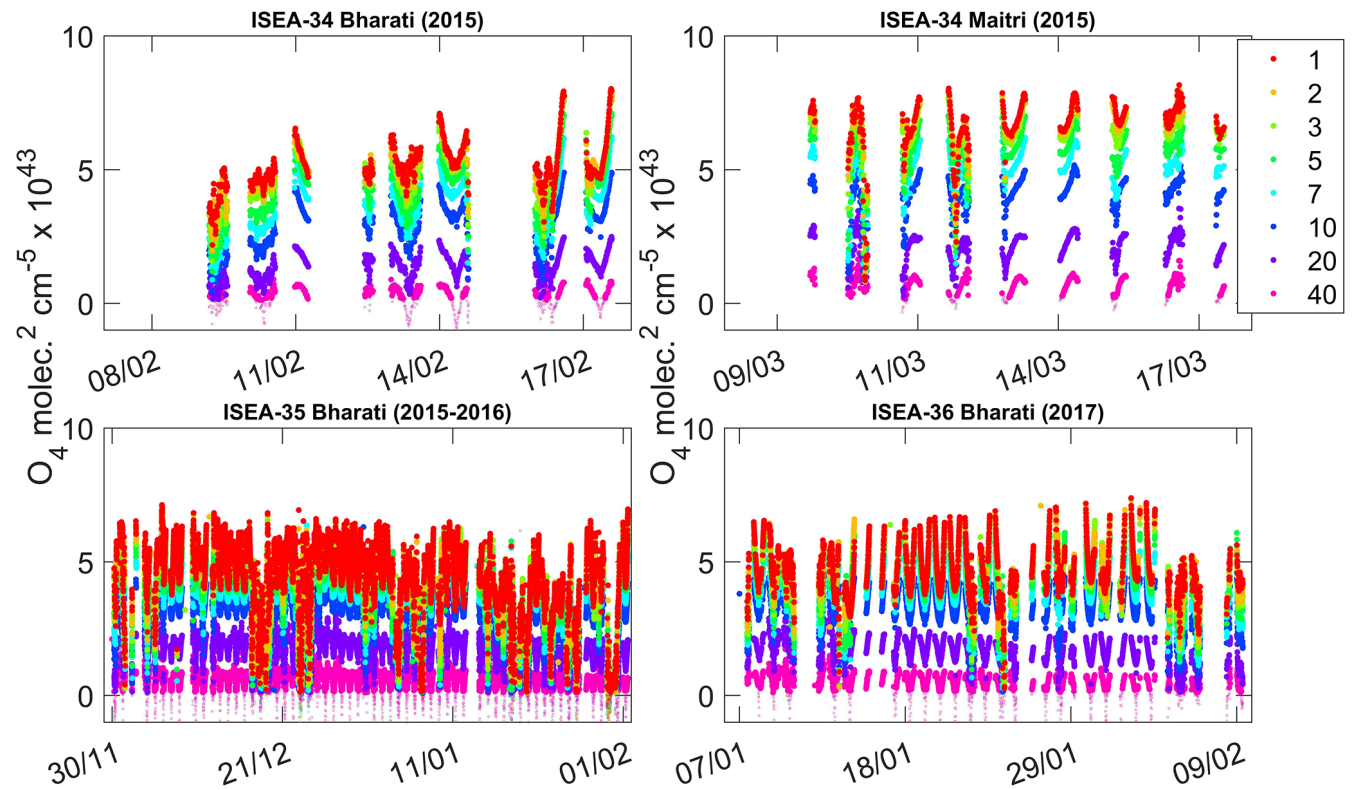

Figure 4. $\mathrm{O}_{4}$ DSCDs observed during the four campaigns are shown. The empty circles represent values below the $2 \sigma$ detection limit of the instrument, while the filled circles are values above the $2 \sigma$ detection limit. The data are color-coded according to elevation angles.
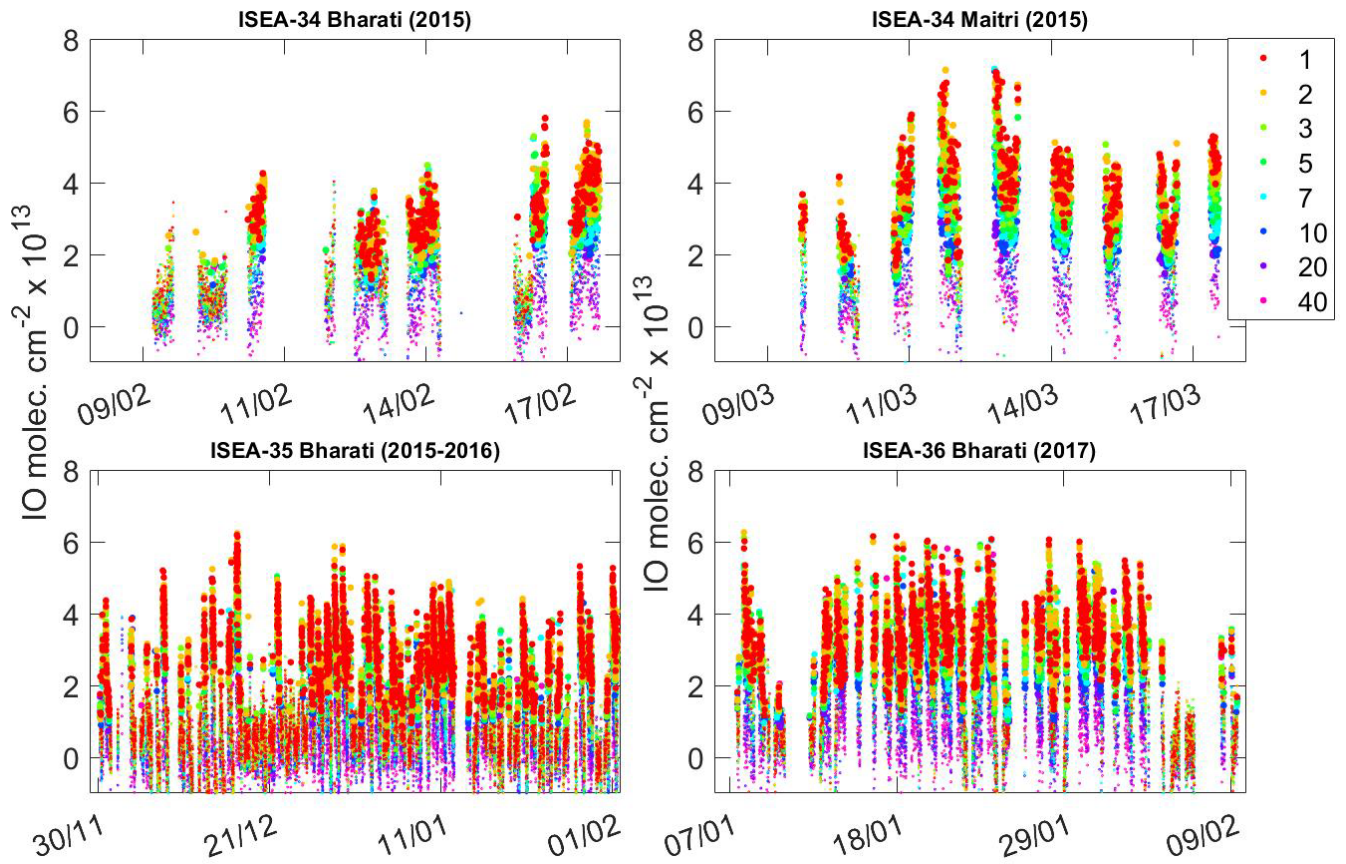

Figure 5. IO DSCDs observed during the four campaigns are shown. The smaller circles represent values below the $2 \sigma$ detection limit of the instrument, while the bigger circles are values above the $2 \sigma$ detection limit. The data are color-coded according to elevation angles.

observed at large SZAs, which is related to an increase in the path length. However, only observations with SZA $<75^{\circ}$ were used to estimate the vertical profiles and surface mixing ratios using the aerosol profiles derived using the $\mathrm{O}_{4}$ DSCDs, as described earlier in Sect. 2. A zoomed-in view of 2 exam- ple days for both the $\mathrm{O}_{4}$ and IO DSCDs is shown in Fig. S2, which clearly shows the decreasing gradient with increasing elevation angles. 

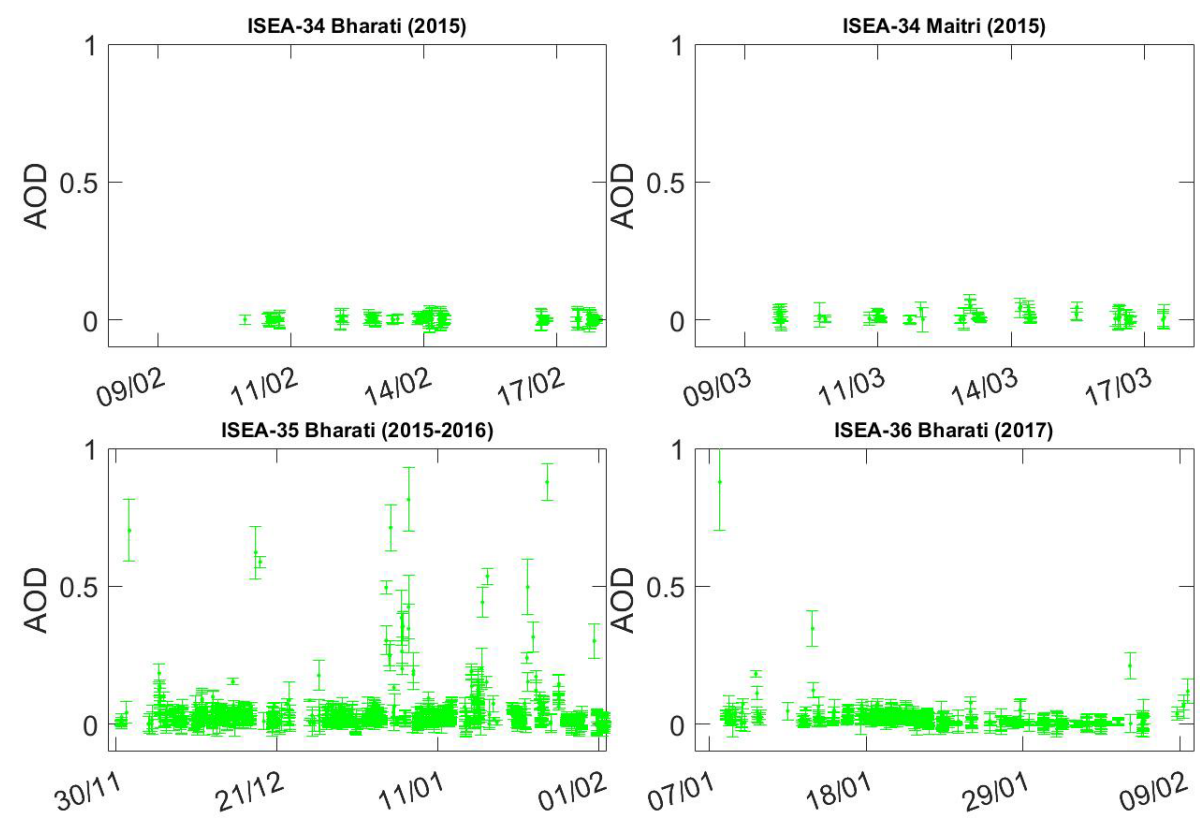

Figure 6. Aerosol optical depth time series retrieved using the $\mathrm{O}_{4}$ DSCDs for all four campaigns are shown. The data show only the "good" data points, which are reliable and were mostly during clear sky conditions.

\subsection{IO vertical column densities (VCDs) and mixing ratio profiles}

The $\mathrm{O}_{4}$ and IO DSCDs were used to retrieve the vertical column densities and the vertical profiles for aerosols and IO. A comparison of the MAX-DOAS-observed $\mathrm{O}_{4}$ DSCDs with the MAPA-modeled DSCDs for all four campaigns are shown in Fig. S3, and Fig. S4 shows a similar plot for the IO DSCDs. Figures 6 and 7 show the MAPA-calculated aerosol optical depths (AODs) and IO VCDs, respectively, for all the campaigns. Several data points are flagged as errors or warnings, with a few scans giving a "valid" flag. In the case of aerosols, the warning or error flags are mainly for scans which were during cloudy weather (Fig. S5 shows the data which were flagged as "bad" and "warning" along with the valid scans). As mentioned above, the cloud cover was regularly measured throughout the campaigns as a part of the meteorological observations. In addition to visual observations, we also computed the cloud index following past works based on MAX-DOAS observations (Mahajan et al., 2012; Wagner et al., 2014), which confirmed that the error and warning flags were during cloud cover periods. For the valid scans, the AODs ranged between 0.002 and 0.016 , with a mean value of 0.003 for ISEA-34 at Bharati; between 0.001 and 0.067 , with a mean value of 0.011 for ISEA-34 at Maitri; between 0.001 and 1.866 , with a mean value of 0.037 for ISEA-35 at Bharati; and between 0.001 and 0.878 , with a mean value of 0.016 for ISEA-36 at Bharati (Fig. 6). The low values are expected considering the pristine conditions in Antarctica, although during a couple of scans elevated levels were observed as demonstrated by the max- imum value during ISEA-35 and ISEA-36. In the case of IO, there were far fewer valid retrieved profiles, as can be seen in Fig. 7 (Fig. S6 shows all scans, including "bad" and "warning"). Only a total of 343 valid scans were retrieved for the vertical profiles of IO. One of the main reasons is that for most of the scans the IO DSCDs at higher elevation angles are below the detection limit and that not enough information is available for the model to retrieve a valid vertical profile. In the case of IO VCDs, there were only two scans that showed a valid flag over the $10 \mathrm{~d}$ period during the ISEA-34 campaign at Bharati due to adverse weather conditions leading to mostly cloudy weather. Thus, the mean VCD value of $2.83 \times 10^{12}$ molec. $\mathrm{cm}^{-2}$ should be treated with some caution. In Maitri during ISEA-34, the IO VCD ranged between $2.37 \times 10^{12}$ and $4.25 \times 10^{12}$ molec. $\mathrm{cm}^{-2}$, with a mean value of $3.40 \pm 0.57 \times 10^{12}$ molec. $\mathrm{cm}^{-2}$. During ISEA-35 at Bharati, which had the highest number of valid scans over the four campaigns, the IO VCDs ranged between $0.01 \times 10^{12}$ and $5.86 \times 10^{12}$ molec. $\mathrm{cm}^{-2}$, with a mean value of $2.62 \pm$ $1.16 \times 10^{12}$ molec. $\mathrm{cm}^{-2}$. During ISEA-36, the IO VCDs ranged between $2.78 \times 10^{12}$ and $4.90 \times 10^{12}$ molec. $\mathrm{cm}^{-2}$, with a mean value of $3.92 \pm 0.79 \times 10^{12}$ molec. $\mathrm{cm}^{-2}$ at Bharati (Table S1 in the Supplement).

In addition to the VCDs, vertical profiles of aerosols (Fig. S7) and IO were estimated using MAPA. Figure 8 shows the typical vertical profiles of IO mixing ratios over the four expeditions. The surface mixing ratios for the valid scans across all the campaigns range between 0.2 and 1.3 pptv (Table S1). The surface $(<30 \mathrm{~m})$ concentrations observed at both Maitri and Bharati are lower than observations in the Weddell Sea region, where summertime concentrations 

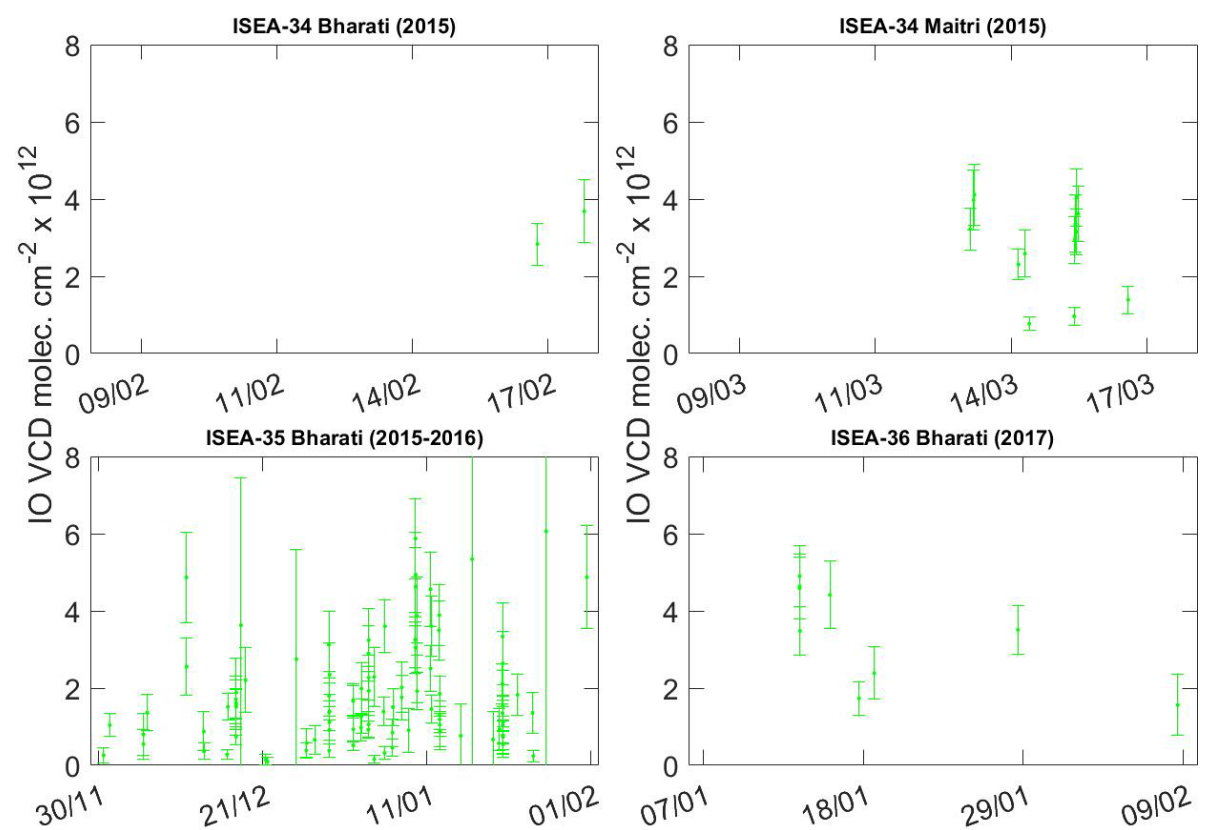

Figure 7. Observations of IO vertical column densities observed throughout all four campaigns are shown. These data were mostly during periods of clear sky and where IO was observed above the detection limit for most of the set elevation angles, enabling a reliable profile retrieval.
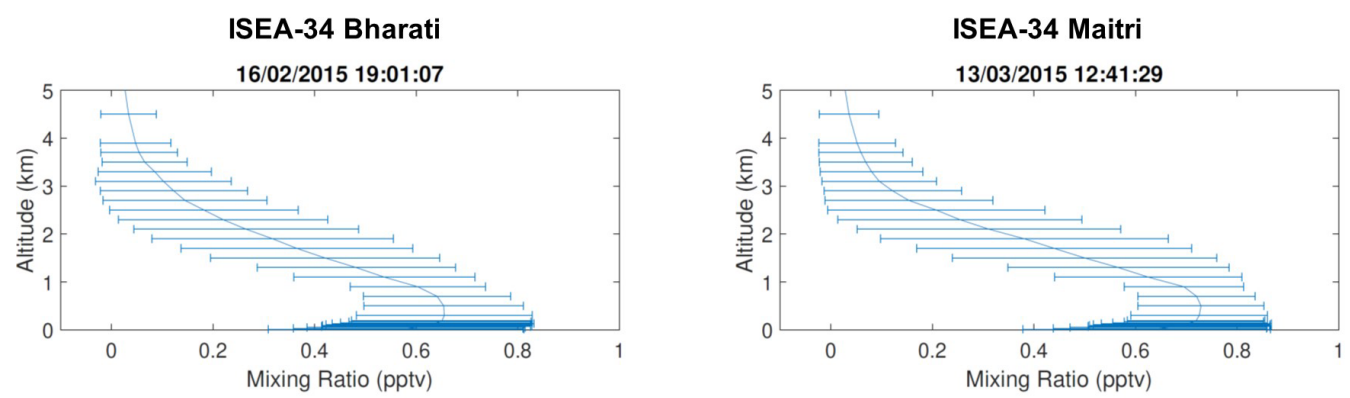

ISEA-35 Bharati15.5

ISEA-36 Bharati
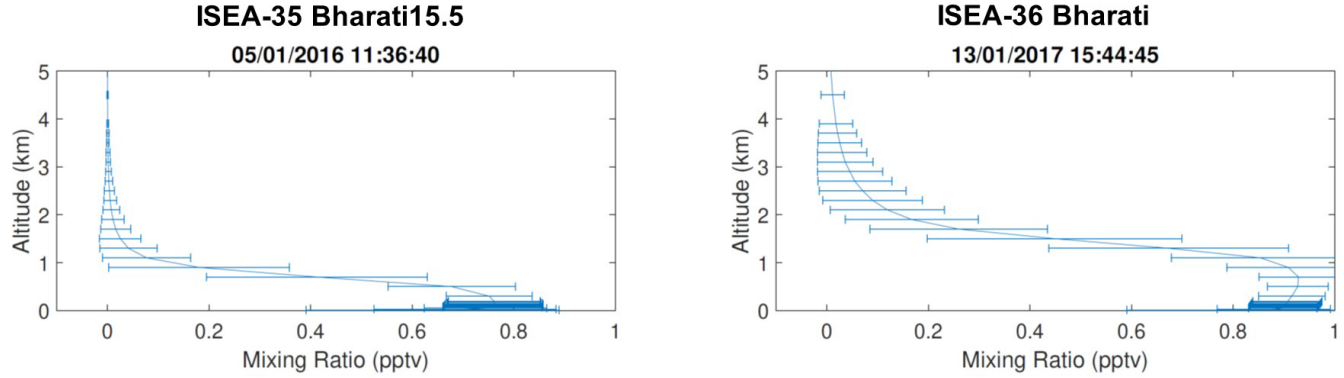

Figure 8. Typical examples of IO vertical profiles retrieved during all four campaigns are shown. The times are in UTC.

exceeding 6 pptv have been reported in the past (Atkinson et al., 2012; Saiz-Lopez et al., 2007a), or at the Neumayer station, where long-term zenith sky DOAS measurements of IO suggest mixing ratios as high as $\sim 10$ pptv during the summer (Frieß et al., 2001). It should be noted that although elevated concentrations were observed at Halley, the average summer concentration, measured only $4 \mathrm{~m}$ above the snow- pack using a long-path DOAS (LP-DOAS) instrument, was about 3 pptv, approximately a factor of 3 higher than the observations at Bharati and Maitri. Considering that the MAXDOAS-retrieved profiles are not very sensitive to the lowermost few meters, this difference is expected. This is because the source of IO is expected to be from the surface, and remote sensing estimates have suggested that high IO concen- 
trations on the order of $50 \mathrm{ppbv}$ are present in the snow interstitial air (Frieß et al., 2010), suggesting that snowpack is indeed the source for iodine compounds. If this is the case, a strong gradient would be observed considering the short lifetime of IO in the atmosphere, and hence the MAX-DOAS observations would be lower than the LP-DOAS observations. However, this does not explain the large difference compared to Neumayer, where the estimated value was 10 pptv. Indeed, Maitri is close to Neumayer, and the reasons for the large difference between the two sites remains a mystery. The observations reported in this study are also similar to measurements at McMurdo Sound, near the Ross Sea, where MAXDOAS observations reported a maximum of $2.6 \pm 0.1 \mathrm{pptv}$ with most of the observations below 1 pptv during 2006 and 2007 (Hay, 2010). It should be noted that the surface values were not highly weighted by the a priori values. McMurdo Sound is also located in the East Antarctic, which shows lower levels of IO in the satellite estimates (Schönhardt et al., 2008) and in models (Fernandez et al., 2019).

Vertical profiles of IO have been reported only once in the past for Antarctica. These measurements were made at McMurdo Sound in East Antarctica (Hay, 2010). IO values over $2 \mathrm{~d}$ in 2006 and 2007 show typical surface concentrations of $\sim 1 \mathrm{pptv}$ (with a maximum of $2.6 \mathrm{pptv}$ ), decreasing to $\sim 0.2 \mathrm{pptv}$ at about $200 \mathrm{~m}$. A second maximum of $0.6 \mathrm{pptv}$ at $\sim 700 \mathrm{~m}$ was also observed, but the models do not reproduce this profile shape, and the observations were subject to large uncertainties, with the vertical profile above $200 \mathrm{~m}$ dominated by the a priori values (Hay, 2010). During the four campaigns studied here, elevated concentrations, similar to the surface, were usually observed until about $400 \mathrm{~m}$. Above this height, there is a decrease, with the retrievals reducing to below 0.1 pptv (Fig. 8). Although the boundary layer height was not available for most of the days, radiosonde observations (not shown) show that the boundary layer height ranged between 300 and $700 \mathrm{~m}$. The means and their standard deviations for the lowest $400 \mathrm{~m}$ for the different campaigns are given in Table S1. The reducing standard deviations in the profile retrieval with altitude show that all the profiles which reproduce elevated IO close to the ground approach zero for higher altitudes, suggesting that most of the IO is within the lower part of the troposphere. However, this gradient is much more gradual than estimates predicted using the THAMO one-dimensional model at Halley Bay (SaizLopez et al., 2008). In most models, the assumption is that the source is from the snowpack, and hence a strong decreasing gradient with altitude has been predicted (Saiz-Lopez et al., 2008). The gradient of this decrease depends on the photolysis of the higher oxides and on the recycling of iodine reservoir species in aerosols, both of which have uncertainties. When the gradient was estimated in 2008 (Saiz-Lopez et al., 2008), the photolysis rates for the higher iodine oxides were not available, but this has recently been measured in the laboratory (Lewis et al., 2020), and THAMO needs to be updated accordingly. Another important point to consider

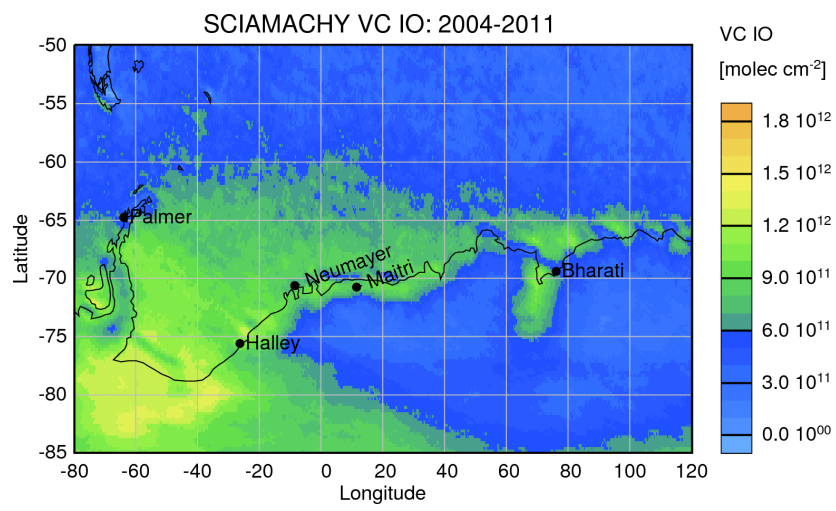

Figure 9. Averaged VCDs of IO retrieved by SCIAMACHY between 2004 and 2011 are shown. Observations suggest that lower levels of IO are expected at Bharati and Maitri compared to Halley Bay and Neumayer.

is that the MAX-DOAS-observation-based profile retrievals typically get only a couple of points of information in the boundary layer and are hence not expected to capture this strong decrease.

\subsection{Comparison with satellite-based estimates}

The satellite-based vertical column densities of IO across the Weddell Sea region and the region encompassing Bharati and Maitri are shown in Fig. 9. The averaged satellite-based VCD observations suggest that lower levels of IO are expected at both the Indian bases compared to places where ground-based observations have been reported in the past, such as Halley Bay and Neumayer. The mean and standard deviation over the 8 years of observations for Bharati is $0.6 \pm 0.5 \times 10^{12}$ molec. $\mathrm{cm}^{-2}$, while for Maitri the amount is $0.5 \pm 0.5 \times 10^{12}$ molec. $\mathrm{cm}^{-2}$, each for the whole time series. For single months the values can be higher: the mean IO VCD for Bharati is 0.8 or $0.4 \times 10^{12}$ molec. $\mathrm{cm}^{-2}$ in December or February, respectively, and $0.6 \times 10^{12}$ molec. $\mathrm{cm}^{-2}$ in March for Maitri. This is lower than the mean value of $2.62 \pm 1.16 \times 10^{12}$ molec. $\mathrm{cm}^{-2}$ observed at Bharati during ISEA-35, which was the longest dataset available in this study, suggesting that the ground-based instruments observe larger VCDs compared to the satellite-based instruments. However, it should be noted that the SCIAMACHY data are an average over all the seasons, and individual daily data points as high as $2.1 \times 10^{12}$ molec. $\mathrm{cm}^{-2}$ have been observed. Figure 10 shows the time series for Bharati and Maitri with daily averages (red dots), as well as monthly averages (blue triangles), for the years 2004 to 2011. Satellite measurements from within $500 \mathrm{~km}$ around the stations were included in the analysis. It should be mentioned that this spatial averaging could cause the introduction of larger uncertainties due to the heterogeneity in the IO distribution, but it is necessary to improve the signal to noise. 

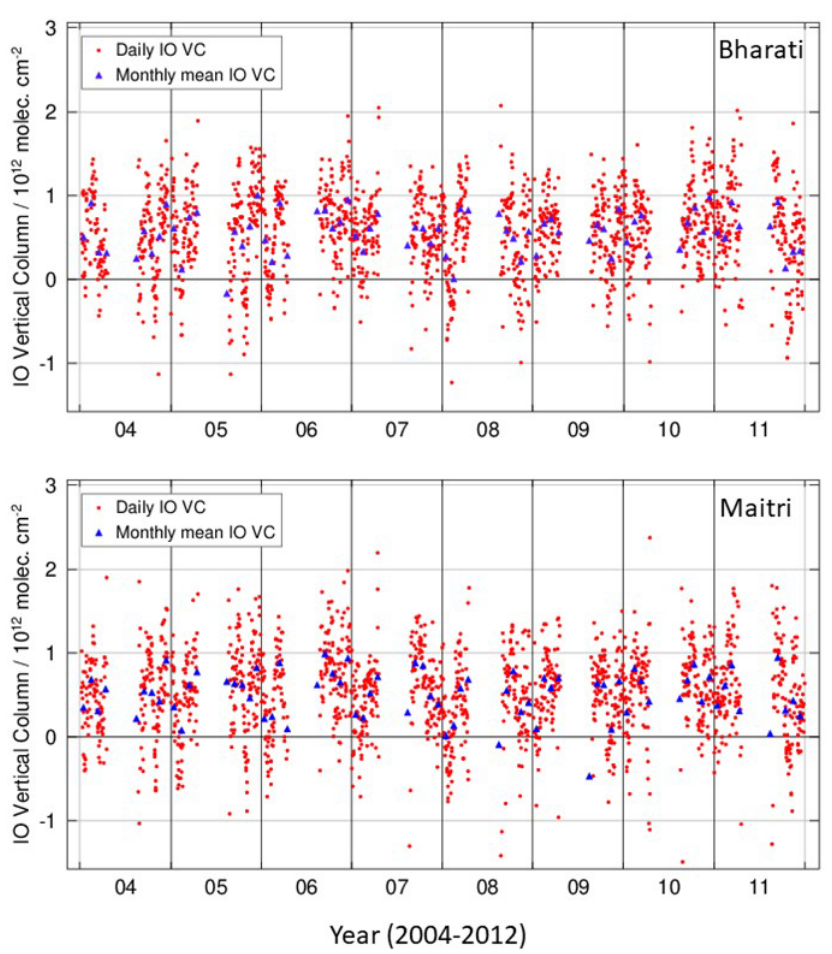

Figure 10. Time series of IO VCD observations at Bharati station retrieved by SCIAMACHY. The monthly mean values are shown in blue, and the daily data points are shown in red.

When the whole IO column is constrained to the lower $400 \mathrm{~m}$, the satellite-retrieved VCDs translate to a range between 0.6 and 1.3 pptv. The daily satellite VCDs tend to exceed these averaged values and result in mixing ratios as high as 2 pptv. This is similar to the range observed throughout the four campaigns reported here. However, observations during the springtime were not made over these four campaigns, when emissions of iodine species have been shown to peak at Halley Bay (Saiz-Lopez et al., 2007a). During the spring season, values as high as $20 \mathrm{pptv}$ were observed at Halley Bay, a factor of 10 higher than during the summer at the Indian stations. However, the satellite observations do not show a large peak over the springtime over both Indian stations. Another outstanding question is whether the satellites are sensitive to the lower $100-200 \mathrm{~m}$, considering the strong gradient in IO. Figure S8 shows the block AMFs for satellite retrievals demonstrating a significant difference between the block AMFs over Antarctica at different albedo values. Over the ice-covered regions in Antarctica, the satellite is sensitive to the lower troposphere as the albedo is usually 0.9 or above. Observations have shown that open water has an albedo of 0.05-0.2 (Jin et al., 2004), whereas the albedo of sea ice ranges between 0.6 and 0.7 for bare ice and $0.8-0.9$ for snowcovered ice (Perovich et al., 2002). In the case of Bharati, Quilty Bay is not ice-covered during the summer, and hence along the light path in Bharati, the sensitivity of the satellite is much lower. The use of a higher albedo would result in an underestimation of the VCD by the satellite, which is the case when compared to the ground-based instruments. At Maitri this should not be the case considering that Maitri is $125 \mathrm{~km}$ inland from the coast, and the ice shelf is less than $1 \mathrm{~km}$ from the station along the light path. It should be noted that the MAPA LUTs are calculated for a low surface albedo (5\%), and hence, at least for some of the measurements, the surface albedo is probably much higher, especially at Maitri. As far as we understand, the effect of the surface albedo mainly cancels out in the MAX-DOAS analysis, but it could be one possible uncertainty in the retrieval results. Another reason for the discrepancy between the ground-based and satelliteretrieved VCDs could be the overpass time, which was approximately 09:00 LT. Although this should not be a large factor during the summer months due to long sunlit hours and given that the numbers provided above were averages throughout the entire campaign for the ground-based observations, measurements at Halley Bay have shown a strong diurnal profile peaking at noon (Saiz-Lopez et al., 2007a). Hence, it is possible that the ground-based observations, which are filtered for $\mathrm{SZA}>75^{\circ}$, capture higher values than the satellite.

Finally, a point to consider is that the satellite data available from SCIAMACHY is for the period of 2004-2011, whereas the MAX-DOAS observations were conducted over three summers from 2015 to 2017. This temporal discrepancy, although small considering the long satellite dataset, could contribute to the difference in the retrieved VCDs. Recent observations of iodine in ice cores in the Alpine region and over Greenland have shown an increasing trend for atmospheric iodine in the Northern Hemisphere (Cuevas et al., 2018; Legrand et al., 2018). In the Antarctic only seasonal and geographical variations in halogens in the ice have been studied, and no long-term dataset is available (Vallelonga et al., 2017). The main cause for this increase is suggested to be an increase in tropospheric ozone, which drives the emission of iodine compounds from the ocean surface through heterogenous chemistry at the ocean interstitial surface (Carpenter et al., 2013). Although questions regarding the strength of this inorganic source in affecting IO concentrations in the Southern Ocean remain (Inamdar et al., 2020; Mahajan et al., 2019), it is possible that the discrepancy between the satellite- and ground-based data is because of a different time period. However, no increasing trend was observed in the satellite data for the period between 2004 and 2011 (Fig. 10), which suggests that a factor of 3 increase in the VCDs is most likely due to a difference in the measurement technique and sensitivities rather than a change in the emissions.

\subsection{Air mass origin dependence}

Year-long observations at Halley Bay in West Antarctica, which were made using the LP-DOAS instrument, suggested a oceanic primary source (Saiz-Lopez et al., 2007a). 
The authors showed through the tracking of air mass backtrajectories that elevated levels of IO were present in air masses that passed over the coastal and oceanic regions compared to the air masses that had only continental exposures. However, even in air masses that had passed only over the continent for the past $5 \mathrm{~d}$, the IO levels were still above the detection limit, which suggested that even if the primary source is oceanic, a secondary source from the snow pack contributed to the atmospheric IO. Indeed, subsequent studies have tried to explain the snowpack source through recycling of primary emissions from the ocean (Fernandez et al., 2019), and one study has even suggested a strong snowpack source based on simulated observations (Frieß et al., 2010). Although the levels of IO are much lower than the peak concentrations seen at Halley Bay, we studied the back-trajectories to see if the origin of air masses leads to a difference in the observed IO levels at both Bharati and Maitri. Considering the short lifetime of reactive iodine compounds in the atmosphere, we calculated the exposure of each HYSPLIT-calculated back-trajectory according to the region it passed over in the last $12 \mathrm{~h}$. Depending on where the trajectories spend the most amount of time, they were classified into coastal, continental, and oceanic air masses. The coastal region was defined as a $0.5^{\circ}$ belt along the Antarctic coastline, with regions to the north and south of this belt considered to be oceanic and continental even though most of them had a coastal origin when the $5 \mathrm{~d}$ trajectories are considered (Fig. S9). Using the profiles which were valid, no clear dependence on the air mass origin was observed. Indeed, most of the data points at both stations corresponded to air masses which were either coastal or continental (Fig. S10) and are representative of the typical wind patterns during the summer season. Thus, using this dataset, it was not possible to draw any conclusions regarding the possible sources of IO in this region, and a longer study is needed in the future.

\section{Conclusions}

This study presents observations of iodine oxide (IO) at the Indian Antarctic bases of Maitri and Bharati made over three summers from 2015 through 2017. IO was observed intermittently during all the campaigns with mixing ratios below 2 pptv. Using a profile retrieval algorithm, vertical gradients of IO were estimated, and these showed a decreasing profile with a peak in the boundary layer. The vertical profiles confirmed the past hypothesis of a source from the ground considering a sharp gradient. The vertical columns observed using the ground-based instrument are approximately a factor of 3-5 higher than the climatological mean observed by the satellite, which could be due to a difference in the measurement techniques and sensitivities. Air mass origin analysis using back-trajectories did not lead to a conclusive answer about the source regions. Indeed, it raises new questions about comparisons with past observations, which show that we still do not understand iodine chemistry in the polar regions. This study suggests that a longer dataset over different seasons and regions of Antarctica is necessary to answer the outstanding questions regarding the sources and seasonal importance of IO in the Indian Ocean sector of Antarctica.

Code and data availability. All the MATLAB codes and data used for analysis of this study are available at https://doi.org/10.17632/wvh25bxzpb.2 (Mahajan, 2021).

Supplement. The supplement related to this article is available online at: https://doi.org/10.5194/acp-21-11829-2021-supplement.

Author contributions. ASM conceptualized the research plan and methodology, did the analysis, and wrote the manuscript. MSB did the field observations. SB, TW, NB, and ASL helped with the interpretation of the observations, and AS provided the satellite observations and helped interpret them.

Competing interests. The authors declare that they have no conflict of interest.

Disclaimer. Publisher's note: Copernicus Publications remains neutral with regard to jurisdictional claims in published maps and institutional affiliations.

Acknowledgements. We thank the logistical and scientific teams of the ISEA-34, ISEA-35, and ISEA-36 campaigns for enabling observations throughout the expeditions. The ISEA campaigns are organized by the National Centre for Polar and Ocean Research (NCPOR), Ministry of Earth Sciences (MOES), Government of India. IITM and NCPOR are funded by MOES, Government of India.

Review statement. This paper was edited by Jayanarayanan Kuttippurath and reviewed by one anonymous referee. 


\section{References}

Allan, J. D., Williams, P. I., Najera, J., Whitehead, J. D., Flynn, M. J., Taylor, J. W., Liu, D., Darbyshire, E., Carpenter, L. J., Chance, R., Andrews, S. J., Hackenberg, S. C., and McFiggans, G.: Iodine observed in new particle formation events in the Arctic atmosphere during ACCACIA, Atmos. Chem. Phys., 15, 55995609, https://doi.org/10.5194/acp-15-5599-2015, 2015.

Atkinson, H. M., Huang, R.-J., Chance, R., Roscoe, H. K., Hughes, C., Davison, B., Schönhardt, A., Mahajan, A. S., Saiz-Lopez, A., Hoffmann, T., and Liss, P. S.: Iodine emissions from the sea ice of the Weddell Sea, Atmos. Chem. Phys., 12, 11229-11244, https://doi.org/10.5194/acp-12-11229-2012, 2012.

Barrie, L. A., Bottenheim, J. W., Schnell, R. C., Crutzen, P. J., and Rasmussen, R. A.: Ozone destruction and photochemical reactions at polar sunrise in the lower Arctic atmosphere, Nature, 334, 138-141, http://www.nature.com/nature/journal/v334/ n6178/abs/334138a0.html (last access: 3 May 2012), 1988.

Beirle, S., Dörner, S., Donner, S., Remmers, J., Wang, Y., and Wagner, T.: The Mainz profile algorithm (MAPA), Atmos. Meas. Tech., 12, 1785-1806, https://doi.org/10.5194/amt-121785-2019, 2019.

Bogumil, K., Orphal, J., Homann, T., Voigt, S., Spietz, P., Fleischmann, O. C., Vogel, A., Hartmann, M., Kromminga, H., Bovensmann, H., Frerick, J., and Burrows, J. P.: Measurements of molecular absorption spectra with the SCIAMACHY preflight model: instrument characterization and reference data for atmospheric remote-sensing in the $230-2380 \mathrm{~nm}$ region, J. Photoch. Photobio. A, 157, 167-184, https://doi.org/10.1016/S10106030(03)00062-5, 2003.

Bottenheim, J. W., Gallant, A. G., and Brice, K. A.: Measurements of $\mathrm{NO}_{y}$ Species and $\mathrm{O}_{3}$ at 82 -Degrees-N Latitude, Geophys. Res. Lett., 13, 113-116, 1986.

Burrows, J. P., Hölzle, E., Goede, A. P. H., Visser, H., and Fricke, W.: SCIAMACHY - Scanning Imaging Absorption Spectrometer for Atmospheric Chartography, Acta Astronaut., 35, 445-451, 1995.

Buys, Z., Brough, N., Huey, L. G., Tanner, D. J., von Glasow, R., and Jones, A. E.: High temporal resolution $\mathrm{Br}_{2}, \mathrm{BrCl}$ and $\mathrm{BrO}$ observations in coastal Antarctica, Atmos. Chem. Phys., 13, 1329-1343, https://doi.org/10.5194/acp-13-1329-2013, 2013.

Carpenter, L. J., Wevill, D. J., Palmer, C. J., and Michels, J.: Depth profiles of volatile iodine and bromine-containing halocarbons in coastal Antarctic waters, Mar. Chem., 103, 227-236, 2007.

Carpenter, L. J., MacDonald, S. M., Shaw, M. D., Kumar, R., Saunders, R. W., Parthipan, R., Wilson, J., and Plane, J. M. C.: Atmospheric iodine levels influenced by sea surface emissions of inorganic iodine, Nat. Geosci., 6, 108-111, https://doi.org/10.1038/ngeo1687, 2013.

Chance, K. V and Spurr, R. J.: Ring effect studies: Rayleigh scattering, including molecular parameters for rotational Raman scattering, and the Fraunhofer spectrum., Appl. Opt., 36, 5224-5230, 1997.

Chaubey, J. P., Krishna Moorthy, K., Suresh Babu, S., and Nair, V. S.: The optical and physical properties of atmospheric aerosols over the Indian Antarctic stations during southern hemispheric summer of the International Polar Year 2007-2008, Ann. Geophys., 29, 109-121, https://doi.org/10.5194/angeo-29-109-2011, 2011.
Cuevas, C. A., Maffezzoli, N., Corella, J. P., Spolaor, A., Vallelonga, P., Kjær, H. A., Simonsen, M., Winstrup, M., Vinther, B., Horvat, C., Fernandez, R. P., Kinnison, D., Lamarque, J.-F., Barbante, C., and Saiz-Lopez, A.: Rapid increase in atmospheric iodine levels in the North Atlantic since the mid-20th century, Nat. Commun., 9, 1452, https://doi.org/10.1038/s41467-018-03756-1, 2018.

Deutschmann, T., Beirle, S., Frieß, U., Grzegorski, M., Kern, C., Kritten, L., Platt, U., Prados-Román, C., Pukite, J., Wagner, T., Werner, B., and Pfeilsticker, K.: The Monte Carlo atmospheric radiative transfer model McArtim: Introduction and validation of Jacobians and 3D features, J. Quant. Spectrosc. Ra., 112, 11191137, https://doi.org/10.1016/j.jqsrt.2010.12.009, 2011.

Draxler, R. and Rolph, G.: HYSPLIT (HYbrid Single Particle Lagrangian Integrated Trajectory). Model access via NOAA ARL Ready, online, available at: https://www.ready.noaa.gov/ HYSPLIT.php (last access: 20 September 2020), 2003.

Fayt, C. and Van Roozendael, M.: QDOAS 1.00. Software User Manual, online, available at: http://uv-vis.aeronomie.be/ software/QDOAS/ (last access: 20 September 2020), 2013.

Fernandez, R. P., Carmona-Balea, A., Cuevas, C. A., Barrera, J. A., Kinnison, D. E., Lamarque, J., Blaszczak-Boxe, C., Kim, K., Choi, W., Hay, T., Blechschmidt, A., Schönhardt, A., Burrows, J. P., and Saiz-Lopez, A.: Modeling the Sources and Chemistry of Polar Tropospheric Halogens $(\mathrm{Cl}, \mathrm{Br}$, and I) Using the CAMChem Global Chemistry-Climate Model, J. Adv. Model. Earth Sy., 11, 2259-2289, https://doi.org/10.1029/2019MS001655, 2019.

Fogelqvist, E. and Tanhua, T.: Iodinated C1-C4 hydrocarbons released from ice algae in Antarctica BT - Naturally-Produced Organohalogens, edited by: Grimvall, A. and de Leer, E. W. B., 295-305, Springer Netherlands, Dordrecht, 1995.

Frieß, U., Wagner, T., Pundt, I., Pfeilsticker, K., Platt, U., and Friefi, U.: Spectroscopic Measurements of Tropospheric Iodine Oxide at Neumayer Station, Antarctica, Geophys. Res. Lett., 28, 19411944, 2001.

Frieß, U., Deutschmann, T., Gilfedder, B. S., Weller, R., and Platt, U.: Iodine monoxide in the Antarctic snowpack, Atmos. Chem. Phys., 10, 2439-2456, https://doi.org/10.5194/acp-102439-2010, 2010.

Garrison, D. L. and Buck, K. R.: The biota of Antarctic pack ice in the Weddell sea and Antarctic Peninsula regions, Polar Biol., 10, 211-219, https://doi.org/10.1007/BF00238497, 1989.

Gómez Martín, J. C., Spietz, P., and Burrows, J. P.: Spectroscopic studies of the I-2/O-3 photochemistry - Part 1: Determination of the absolute absorption cross sections of iodine oxides of atmospheric relevance, J. Photoch. Photobio. A, 176, 15-38, https://doi.org/10.1016/j.jphotochem.2005.09.024, 2005.

Grilli, R., Legrand, M., Kukui, A., Méjean, G., Preunkert, S., and Romanini, D.: First investigations of $\mathrm{IO}, \mathrm{BrO}$, and $\mathrm{NO}_{2}$ summer atmospheric levels at a coastal East Antarctic site using modelocked cavity enhanced absorption spectroscopy., Geophys. Res. Lett., 40, 791-796, https://doi.org/10.1002/GRL.50154, 2013.

Hay, T.: MAX - DOAS measurements of bromine explosion events in McMurdo Sound, Antarctica, University of Canterbury, Canterbury, 2010.

Hollwedel, J., Wenig, M., Beirle, S., Kraus, S., Kühl, S., WilmsGrabe, W., Platt, U., and Wagner, T.: Year-to-Year Variability of Polar Tropospheric BrO as seen by GOME, Adv. Space Res., 34, 804-808, https://doi.org/10.1016/j.asr.2003.08.060, 2004. 
Hönninger, G., von Friedeburg, C., and Platt, U.: Multi axis differential optical absorption spectroscopy (MAX-DOAS), Atmos. Chem. Phys., 4, 231-254, https://doi.org/10.5194/acp-4231-2004, 2004.

Inamdar, S., Tinel, L., Chance, R., Carpenter, L. J., Sabu, P., Chacko, R., Tripathy, S. C., Kerkar, A. U., Sinha, A. K., Bhaskar, P. V., Sarkar, A., Roy, R., Sherwen, T., Cuevas, C., Saiz-Lopez, A., Ram, K., and Mahajan, A. S.: Estimation of reactive inorganic iodine fluxes in the Indian and Southern Ocean marine boundary layer, Atmos. Chem. Phys., 20, 12093-12114, https://doi.org/10.5194/acp-20-12093-2020, 2020.

Jin, Z., Charlock, T. P., Smith, W. L., and Rutledge, K.: A parameterization of ocean surface albedo, Geophys. Res. Lett., 31, 1-4, https://doi.org/10.1029/2004GL021180, 2004.

Koenig, T. K., Baidar, S., Campuzano-Jost, P., Cuevas, C. A., Dix, B., Fernandez, R. P., Guo, H., Hall, S. R., Kinnison, D., Nault, B. A., Ullmann, K., Jimenez, J. L., Saiz-Lopez, A., and Volkamer, R.: Quantitative detection of iodine in the stratosphere, P. Natl. Acad. Sci. USA, 15, 201916828, https://doi.org/10.1073/pnas.1916828117, 2020.

Kreher, K., Johnston, P. V., Wood, S. W., Nardi, B., and Platt, U.: Ground-based measurements of tropospheric and stratospheric $\mathrm{BrO}$ at Arrival Heights, Antarctica, Geophys. Res. Lett., 24, 3021-3024, https://doi.org/10.1029/97GL02997, 1997.

Legrand, M., McConnell, J. R., Preunkert, S., Arienzo, M., Chellman, N., Gleason, K., Sherwen, T., Evans, M. J., and Carpenter, L. J.: Alpine ice evidence of a three-fold increase in atmospheric iodine deposition since 1950 in Europe due to increasing oceanic emissions, P. Natl. Acad. Sci. USA, 115, 12136-12141, https://doi.org/10.1073/pnas.1809867115, 2018.

Lewis, T. R., Gómez Martín, J. C., Blitz, M. A., Cuevas, C. A., Plane, J. M. C., and Saiz-Lopez, A.: Determination of the absorption cross sections of higher-order iodine oxides at 355 and $532 \mathrm{~nm}$, Atmos. Chem. Phys., 20, 10865-10887, https://doi.org/10.5194/acp-20-10865-2020, 2020.

Mahajan, A.: Data as a part of Observations of iodine monoxide over three summers at the Indian Antarctic bases, Bharati and Maitri, [data set], Mendeley Data, V2, https://doi.org/10.17632/wvh25bxzpb.2, 2021.

Mahajan, A. S., Shaw, M., Oetjen, H., Hornsby, K. E., Carpenter, L. J., Kaleschke, L., Tian-Kunze, X., Lee, J. D., Moller, S. J., Edwards, P. M., Commane, R., Ingham, T., Heard, D. E., and Plane, J. M. C.: Evidence of reactive iodine chemistry in the Arctic boundary layer, J. Geophys. Res., 115, D20303, https://doi.org/10.1029/2009JD013665, 2010.

Mahajan, A. S., Gómez Martín, J. C., Hay, T. D., Royer, S.-J., Yvon-Lewis, S., Liu, Y., Hu, L., Prados-Roman, C., Ordóñez, C., Plane, J. M. C., and Saiz-Lopez, A.: Latitudinal distribution of reactive iodine in the Eastern Pacific and its link to open ocean sources, Atmos. Chem. Phys., 12, 11609-11617, https://doi.org/10.5194/acp-12-11609-2012, 2012.

Mahajan, A. S., Tinel, L., Hulswar, S., Cuevas, C. A., Wang, S., Ghude, S., Naik, R. K., Mishra, R. K., Sabu, P., Sarkar, A., Anilkumar, N., and Saiz Lopez, A.: Observations of iodine oxide in the Indian Ocean marine boundary layer: A transect from the tropics to the high latitudes, Atmos. Environ. X, 1, 100016, https://doi.org/10.1016/j.aeaoa.2019.100016, 2019.

Meller, R. and Moortgat, G. K.: Temperature dependence of the absorption cross sections of formaldehyde between 223 and $323 \mathrm{~K}$ in the wavelength range $225-375 \mathrm{~nm}$, J. Geophys. Res., 105, 7089-7101, https://doi.org/10.1029/1999JD901074, 2000.

O’Dowd, C. D., Facchini, M. C., Cavalli, F., Ceburnis, D., Mircea, M., Decesari, S., Fuzzi, S., Yoon, Y. J., Putaud, J. P., and Dowd, C. D. O.: Biogenically driven organic contribution to marine aerosol, Nature, 431, 676-680, https://doi.org/10.1038/nature02959, 2004.

Oltmans, S. J. and Komhyr, W. D.: Surface Ozone Distributions and Variations from 1973-1984 Measurements at the Noaa Geophysical Monitoring for Climatic-Change Base-Line Observatories, J. Geophys. Res.-Atmos., 91, 5229-5236, 1986.

Perovich, D. K., Grenfell, T. C., Light, B., and Hobbs, P. V.: Seasonal evolution of the albedo of multiyear Actic sea ice, J. Geophys. Res.-Oceans, 107, SHE 20-1-SHE 20-13, https://doi.org/10.1029/2000jc000438, 2002.

Platt, U. and Stutz, J.: Differential optical absorption spectroscopy: Principles and applications, First Ed., Springer-Verlag, Berlin, Heidelberg, https://doi.org/10.1007/978-3-540-75776-4, 2008.

Raso, A. R. W., Custard, K. D., May, N. W., Tanner, D., Newburn, M. K., Walker, L., Moore, R. J., Huey, L. G., Alexander, L., Shepson, P. B., and Pratt, K. A.: Active molecular iodine photochemistry in the Arctic, P. Natl. Acad. Sci. USA, 114, 10053-10058, https://doi.org/10.1073/pnas.1702803114, 2017.

Reifenhäuser, W. and Heumann, K. G.: Determinations of methyliodine in the antarctic atmosphere at the south polar sea, Atmos. Environ. A-Gen., 26, 2905-2912, 1992.

Richter, A., Wittrock, F., Ladstätter-Weißenmayer, A., and Burrows, J. P.: GOME measurements of stratospheric and tropospheric BrO, Adv. Space Res., 29, 1667-1672, 2002.

Rothman, L. S., Gordon, I. E., Babikov, Y., Barbe, A., Chris Benner, D., Bernath, P. F., Birk, M., Bizzocchi, L., Boudon, V., Brown, L. R., Campargue, A., Chance, K., Cohen, E. a., Coudert, L. H., Devi, V. M., Drouin, B. J., Fayt, A., Flaud, J.-M., Gamache, R. R., Harrison, J. J., Hartmann, J.-M., Hill, C., Hodges, J. T., Jacquemart, D., Jolly, A., Lamouroux, J., Le Roy, R. J., Li, G., Long, D. a., Lyulin, O. M., Mackie, C. J., Massie, S. T., Mikhailenko, S., Müller, H. S. P., Naumenko, O. V., Nikitin, A. V., Orphal, J., Perevalov, V., Perrin, A., Polovtseva, E. R., Richard, C., Smith, M. a. H., Starikova, E., Sung, K., Tashkun, S., Tennyson, J., Toon, G. C., Tyuterev, V. G., and Wagner, G.: The HITRAN 2012 molecular spectroscopic database, J. Quant. Spectrosc. Ra., 130, 4-50, https://doi.org/10.1016/j.jqsrt.2013.07.002, 2013.

Saiz-Lopez, A. and Blaszczak-boxe, C. S.: The polar iodine paradox, Atmos. Environ., 145, 72-73, https://doi.org/10.1016/j.atmosenv.2016.09.019, 2016.

Saiz-Lopez, A. and von Glasow, R.: Reactive halogen chemistry in the troposphere., Chem. Soc. Rev., 41, 6448-6472, https://doi.org/10.1039/C2CS35208G, 2012.

Saiz-Lopez, A., Mahajan, A. S., Salmon, R. A., Bauguitte, S. J.B., Jones, A. E., Roscoe, H. K., and Plane, J. M. C.: Boundary Layer Halogens in Coastal Antarctica, Science, 317, 348-351, https://doi.org/10.1126/science.1141408, 2007a.

Saiz-Lopez, A., Chance, K. V., Liu, X., Kurosu, T. P., and Sander, S. P.: First observations of iodine oxide from space, Geophys. Res. Lett., 34, L12812, https://doi.org/10.1029/2007GL030111, 2007b.

Saiz-Lopez, A., Plane, J. M. C., Mahajan, A. S., Anderson, P. S., Bauguitte, S. J.-B., Jones, A. E., Roscoe, H. K., Salmon, R. 
A., Bloss, W. J., Lee, J. D., and Heard, D. E.: On the vertical distribution of boundary layer halogens over coastal Antarctica: implications for $\mathrm{O}_{3}, \mathrm{HO}_{x}, \mathrm{NO}_{x}$ and the $\mathrm{Hg}$ lifetime, Atmos. Chem. Phys., 8, 887-900, https://doi.org/10.5194/acp-8887-2008, 2008.

Saiz-Lopez, A., Plane, J. M. C., Baker, A. R., Carpenter, L. J., von Glasow, R., Martín, J. C. G., McFiggans, G. B., Saunders, R. W., and Gómez Martín, J. C.: Atmospheric Chemistry of Iodine, Chem. Rev., 112, 1773-1804, https://doi.org/10.1021/cr200029u, 2012.

Saiz-Lopez, A., Blaszczak-Boxe, C. S., and Carpenter, L. J.: A mechanism for biologically induced iodine emissions from sea ice, Atmos. Chem. Phys., 15, 9731-9746, https://doi.org/10.5194/acp-15-9731-2015, 2015a.

Saiz-Lopez, A., Baidar, S., Cuevas, C. A., Koenig, T. K., Fernandez, R. P., Dix, B., Kinnison, D. E., Lamarque, J., RodriguezLloveras, X., Campos, T. L., and Volkamer, R.: Injection of iodine to the stratosphere, Geophys. Res. Lett., 42, 6852-6859, https://doi.org/10.1002/2015GL064796, 2015b.

Schönhardt, A., Richter, A., Wittrock, F., Kirk, H., Oetjen, H., Roscoe, H. K., and Burrows, J. P.: Observations of iodine monoxide columns from satellite, Atmos. Chem. Phys., 8, 637-653, https://doi.org/10.5194/acp-8-637-2008, 2008.

Schönhardt, A., Begoin, M., Richter, A., Wittrock, F., Kaleschke, L., Gómez Martín, J. C., and Burrows, J. P.: Simultaneous satellite observations of $\mathrm{IO}$ and $\mathrm{BrO}$ over Antarctica, Atmos. Chem. Phys., 12, 6565-6580, https://doi.org/10.5194/acp-126565-2012, 2012.

Stutz, J., Kim, E. S., Platt, U., Bruno, P., Perrino, C., and Febo, A.: UV-visible absorption cross sections of nitrous acid, J. Geophys. Res., 105, 14585-14592, 2000.

Thalman, R. and Volkamer, R. A.: Temperature Dependent Absorption Cross-Sections of $\mathrm{O}_{2}-\mathrm{O}_{2}$ collision pairs between 340 and $630 \mathrm{~nm}$ and at atmospherically relevant pressure, Phys. Chem. Chem. Phys., 15, 15371-15381, https://doi.org/10.1039/C3CP50968K, 2013.

Theys, N., Van Roozendael, M., Hendrick, F., Yang, X., De Smedt, I., Richter, A., Begoin, M., Errera, Q., Johnston, P. V., Kreher, K., and De Mazière, M.: Global observations of tropospheric BrO columns using GOME-2 satellite data, Atmos. Chem. Phys., 11, 1791-1811, https://doi.org/10.5194/acp-11-1791-2011, 2011.

Tuckermann, M., Ackermann, R., Golz, C., LorenzenSchmidt, H., Senne, T., Stutz, J., Trost, B., Unold, W., and Platt, U.: DOASobservation of halogen radical-catalysed arctic boundary layer ozone destruction during the ARCTOC-campaigns 1995 and 1996 in Ny-Alesund, Spitsbergen, Tellus B, 49B, 533-555, 1997.
Vallelonga, P., Maffezzoli, N., Moy, A. D., Curran, M. A. J., Vance, T. R., Edwards, R., Hughes, G., Barker, E., Spreen, G., SaizLopez, A., Corella, J. P., Cuevas, C. A., and Spolaor, A.: Sea-icerelated halogen enrichment at Law Dome, coastal East Antarctica, Clim. Past, 13, 171-184, https://doi.org/10.5194/cp-13-1712017, 2017.

Vandaele, A. C., Hermans, C., Simon, P. C., Carleer, M. R., Colin, R., Fally, S., Merienne, M. F., Jenouvrier, A., and Coquartii, B.: Measurements od the $\mathrm{NO}_{2}$ absorption cross-section from $42000 \mathrm{~cm}^{-1}$ to $10000 \mathrm{~cm}^{-1}(238-1000 \mathrm{~nm})$ at $220 \mathrm{~K}$ and 294 K, J. Quant. Spectrosc. Ra., 59, 171-184, 1998.

Wagner, T., Leue, C., Wenig, M., Pfeilsticker, K., and Platt, U.: Spatial and temporal distribution of enhanced boundary layer $\mathrm{BrO}$ concentrations measured by the GOME instrument aboard ERS2, J. Geophys. Res.-Atmos., 106, 24225-24235, 2001.

Wagner, T., Dix, B., Friedeburg, C. V., Frieß, U., Sanghavi, S., Sinreich, R., and Platt, U.: MAX-DOAS $\mathrm{O}_{4}$ measurements: A new technique to derive information on atmospheric aerosols - Principles and information content, J. Geophys. Res., 109, D22205, https://doi.org/10.1029/2004JD004904, 2004.

Wagner, T., Beirle, S., and Deutschmann, T.: Three-dimensional simulation of the Ring effect in observations of scattered sun light using Monte Carlo radiative transfer models, Atmos. Meas. Tech., 2, 113-124, https://doi.org/10.5194/amt-2113-2009, 2009.

Wagner, T., Apituley, A., Beirle, S., Dörner, S., Friess, U., Remmers, J., and Shaiganfar, R.: Cloud detection and classification based on MAX-DOAS observations, Atmos. Meas. Tech., 7, 1289-1320, https://doi.org/10.5194/amt-7-1289-2014, 2014.

Wagner, T., Beirle, S., Benavent, N., Bösch, T., Chan, K. L., Donner, S., Dörner, S., Fayt, C., Frieß, U., García-Nieto, D., Gielen, C., González-Bartolome, D., Gomez, L., Hendrick, F., Henzing, B., Jin, J. L., Lampel, J., Ma, J., Mies, K., Navarro, M., Peters, E., Pinardi, G., Puentedura, O., Pukīte, J., Remmers, J., Richter, A., Saiz-Lopez, A., Shaiganfar, R., Sihler, H., Van Roozendael, M., Wang, Y., and Yela, M.: Is a scaling factor required to obtain closure between measured and modelled atmospheric $\mathrm{O}_{4}$ absorptions? An assessment of uncertainties of measurements and radiative transfer simulations for 2 selected days during the MAD-CAT campaign, Atmos. Meas. Tech., 12, 2745-2817, https://doi.org/10.5194/amt-12-2745-2019, 2019. 